\title{
Mimari tasarım firmalarında müșteri yönlülük: Bir yapısal denklem modeli
}

\author{
Tülay Çivící \\ Balıkesir Üniversitesi, Mimarlık Fakültesi, Mimarlık Bölümü, Çağış kampüsü, Balıkesir. \\ Gelis Tarihi (Recived Date): 11.05.2017 \\ Kabul Tarihi (Accepted Date): 23.07.2017
}

\section{Özet}

Bu çalışmada mimari tasarım firmalarının müşsteri yönlülüğü incelenmiştir. Çalışma kapsamında, kuramsal bir model geliştirilmiştir. Bu kuramsal model, (1) müşteri memnuniyetlerinin belirlenmesinde kalite beklentisi, kalite algısı, değer algısının etkisinin olduğunu, (2) müşteri memnuniyetinin müşteri sadakatini etkilediğini önermektedir. Kuramsal modelin ileri sürdüğ̈̈ önermeler, inşaat sektöründe faaliyet gösteren 143 yüklenici firmaya yapılan anket çalışmasıyla ampirik olarak test edilmiştir. Kuramsal modelin değişkenlerinin test edilmesi için yapısal denklem modeli kullanılmıştır.

Anahtar kelimeler: Müşteri yönlülük, müşteri memnuniyeti, müşteri sadakati

\section{Customer orientation in architectural design firms: Structural equation modeling}

\begin{abstract}
In this study, the customer orientation of architectural design firms is examined. A conceptual model is developed. These conceptual models proposes that (1) customer satisfaction is determined by quality expectations, perceived quality and perceived value, (2) there is a relationship between customer satisfaction and customer loyalty. These propositions were empirical tested by a survey of 143 contractors. Structural equation modeling was used to estimate the parameters of conceptual model. The research findings reveal that perceived quality and perceived value positively affect. On the other hand, quality expectations negatively affect customer satisfaction. In conclusion, it has been determined that there is a positive relationship between customer satisfaction and customer loyalty
\end{abstract}

Keywords: Customer orientation, customer satisfaction, customer loyalty.

\footnotetext{
* Tülay Çivíci, tulay@ balikesir.edu.tr, http://orcid.org/0000-0002-5764-7951
} 


\section{Giriş}

Temel amacı kar elde etmek olan firmalar ancak müşteriye verdikleri değer ölçüsünde bunu gerçekleştirebilmektedir. Bu nedenle firmaların müşteri yönlü yaklaşımlar benimsemesi firma başarısında büyük önem arz etmektedir. Müşteri istek ve gereksinimlerinin bir araya gelmesi ile beklentiler doğmaktadır. Müşterinin mevcut ve gelecekte oluşacak beklentileri mal ve hizmet üretimini etkilemektedir [1]. Bu nedenle firmaların müşteri beklentilerinin karşılanabileceği müşteri yönlü yaklaşımlar benimsemesi firmanın başarısında büyük katkılar sağlayacaktır. Müşteri yönlülük ancak müşteri için yapılanların sistematik bir şekilde yine müşteri tarafindan değerlendirilmesiyle gerçekleşebilmektedir [2]. Müşterilerin ürün/hizmet konusunda algıları ve beklentilerinin karşılanması onların memnuniyetini etkilemektedir [2]. Aynı zamanda müşteriye yönelik çabalar sadece memnuniyet ekseni ile sınırlı kalmamalıdır. $\mathrm{Bu}$ durumun sadakate dönüştürülmesi önemlidir. Bu sayede işletmelerin rakipleri ile rekabet edebilmesi mümkün olacaktır [3].

Müşteri yönlülük yeni bir kavram değildir. Müşteri yönlülük kavramı yaklaşık olarak 50 yıl önce Levitt [4] tarafından ortaya konulmuş, aradan geçen zaman içinde güncelliğini yitirmemiştir. 1990' l1 yılların başından itibaren yoğunlaşan çalışmalarda müşteri yönlülük kavramı yönetimsel alt disiplin olan pazarlama disiplininde sıklıkla kullanılan bir kavram olarak günümüze kadar gelmiştir [5, 6]. Müşteri yönlülük farklı çalışma alanlarında sıklıkla ele alınan bir konu olmasına rağmen, konuyu inşaat sektörü kapsamında ele alan çalışmalar oldukça azdır. Bu alandaki bilgi boşluğunun tamamlanması, mimarlık hizmetlerinde müşterilerinin rolüne 1şık tutması amaciyla bu çalışma gerçekleştirilmiştir. Çalışmanın örneklemini mimarlık hizmetlerinin müşterilerinden olan yüklenici firmalar oluşturmaktadır. Mimari tasarım firmalarının müşteri yönlülüğü, geliştirilen bir araştırma modeli aracılığıyla ölçülmüştür. Araştırma modelinin değerlendirilmesi için veriler düzenlenen anket çalışması ile elde edilmiştir.

\section{Müşteri kavramı}

Müşteri kelime anlamıyla "belirli bir kurumdan ya da kuruluştan bir ürünü veya hizmeti satın alan (kabul eden) kuruluş kişi ya da kuruluşlar" olarak tanımlanmaktadır [7]. Fakat müşteri kavramı sadece ürün satın alanlarla sınırlı kalmamakta, üretilen mal ve hizmetlerden etkilenen kişilerin tümünü kapsamaktadır [8]. Müşterilerin firma içinde ve dışında olabilir. Bu durumda, firma içindeki diğer bölüm ve kişilerden servis/ürün alan bölüm ve kişiler iç müşteriler, üründen etkilenen fakat ürünü üreten firmanın elemanı olmayan kurum ve kişiler ise diş müşterilerdir.

\section{1. İnşaat sektöründe müşteri kavramı}

İnşaat sektörü, diğer üretim sektörlerinden birçok yönüyle farklılık göstermektedir. Bu farklılıklara rağmen, amaç bir ürün (yapı, yapı grubu) meydana getirmektir. İnşaat sektöründe üretim, uzun ve karmaşık bir süreç içermektedir. $\mathrm{Bu}$ üretim sürecinde birçok katılımcının (kullanıcı, mal sahibi, mühendis, yüklenici, alt yükleniciler, malzeme sağlayıcılar, vb.) yer aldığı çeşitli eylemler (öntasarım, tasarım, inşaat, vb.), farklı düzeyde (sektör, işlem, firma, proje, vb.) gerçekleşmektedir. Üretim sürecinde doğrudan katılımcılar olduğu gibi, üretimin çevresini oluşturan ve sektörü yakından ilgilendiren faaliyet alanları da mevcuttur. $\mathrm{Bu}$ çalışma ortamında ise müşterinin tanımlanması her zaman kolay olmayabilir. Bu nedenle inşaat sektöründe müşteri 
tanımı farklı boyutlarda karşımıza çıkmaktadır. Müşteri; yapımını finanse eden taraf, ana yüklenici ya da bitmiş ürünün alıcısı rollerinden bir ya da birkaçını üstlenebilir [9].

Günaydın [9] çalışmasında inşaat sektöründe müşteri kavramını; "inşaat sektöründe, tasarım aşamasında ürünler teknik çizimler (planlar, kesitler, vb.) keşif-metraj çıktıları, şartnamelerdir. Müşteri ise; mal sahibi, yüklenici firmadır. Yapı üretim aşamasında ise bina ve bina gruplarl ürün, bunları kullananlar müşteridir. Üretim sürecindeki her bir katılımcı (malsahibi, tasarımcı, yüklenici) müşteri rolünü üstlenmektedir. Malsahibi ihtiyaçlarını tasarımcıya verir; tasarımcı malsahibinin müşterisidir. Tasarımcı plan ve şartnameleri hazırlar; yüklenici tasarımcının müşterisi olarak plan ve şartnameleri uygular ve inşaatı tamamlar. Malsahibi bina ve tesisleri yükleniciden devralır; burada malsahibi yüklenicinin müşterisidir" ifadeleriyle tanımlamıştır.

\section{Müşsteri yönlülük}

Firmaların içinde bulundukları pazarda varlıklarını sürdürebilmelerinin en önemli anahtar öğesi, müşteri yönlü bir yönetim felsefesinin benimsenmesidir. Slater ve Narver (1994) müşteri yönlülüğ̈̈; bir firmanın, müşterilerinin ihtiyaç ve beklentileriyle ilgili sürekli bilgi toplamaya odaklanması ve bu bilgiyi, müşteri değeri yaratmak için kullanması olarak tanımlamaktadır [10, 11]. Webster [12]'in tanımına göre ise müşteri yönlülük, firmaların yaptığı her işte müşterileri birinci sıraya koyma ve en üst düzeyde bir hizmet sunumu amacı çerçevesinde tüm etkinlikleri organize etme işidir [13]. Despande vd. [14] müşteri yönlülüğü, uzun dönemli kar elde etmek için yöneticiler ve çalışanlar gibi paydaşları içine alan müşterilerin çıkarlarını birinci sıraya yerleştirmek olarak tanımlamıştır.

Appiah-Adu ve Singh, [15] çalışmasında müşteri yönlülüğü firma kültürünün önemli bir parçası olarak görülmesi gerektiğini vurgulamış, müşteri memnuniyetini içeren bir kavram olarak tanımlamıştır. Gedik [16]' e göre, müşteri memnuniyeti, müşteri yönlü yaklaşımın temelinde yer alan önemli bir parametredir. Bu nedenle firmaların müşteri yönlü yaklaşımlarında ilk adım müşteri memnuniyetidir. Müssteri memnuniyeti, firmalar tarafından ürün/hizmet performansını değerlendirmede kullandıkları temel göstergelerden biridir. Müşteri memnuniyetini; müşterinin ürünü/hizmeti nasıl algıladıkları ve bu ürün/hizmet ile ilgili beklentilerinin neler olduğu belirlemektedir. Beklenti, müşterinin belirli bir ürün/hizmet sonrasında gelecekte ne ile karşılaşacağına yönelik tahminleridir. Kalite beklentisi; dayanıklılık, amaca uygunluk, gibi müşterilerin istediklerini ürün/hizmette görmekte ya da görmeyi bekleme davranışıdır [17]. Zaim vd. [18], müşteri beklentilerinin müşterilerin kişisel ihtiyaçlarının yerine getirilmesi ve müşteri beklentilerinin müşteri memnuniyeti ile ilişkisi olduğunu ileri sürmüştür. $\mathrm{Bu}$ nedenle, beklentilerin bilinmesi, memnuniyetin sağlanması açısından önemlidir. Müşterinin algısı ise, ürün/hizmet alımıyla ilgili beklentilerin, gerçekleşen ile ne kadar örtüştügünü ifade etmektedir. Fonell vd. [19], müşteri algısını, kalite ve değer algıs1 olarak ele almıştır. Kalite algısı, müşterinin beklentisine uygun hizmet alımına karşılık, tekrar satın alma eğiliminin doğmasıdır. Müşterinin ürün/hizmet alımıyla ilgili yargılarının, gerçekleşen hizmet performansı ile ne kadar örtüştüğünün müşteri tarafından değerlendirilmesidir [20]. Değer algısı; müşterinin bir ürün yada hizmet ile ilgili beklediği yararının müşteri tarafından değerlendirilmesidir. Zaim vd. [18], değer algısının müşteri memnuniyeti üzerinde pozitif etkisi olduğunu savunmaktadır. 
$\mathrm{Bu}$ bağlamda, müşteri yönlülükte etkinliğin başarı ölçütü müşteri memnuniyetidir Müşteri memnuiyetinin sağlanmış olması müşteri potansiyellerini arttırmakta, mevcut müşterilerin sadakatini sağlamaktadır. Müşteri sadakati, müşterilerin işletmeye karş1 sürekli olumlu tutumu ve tekrar satın alma davranışı olarak tanımlanır. Sadakatin bir davranışsal yönü, bir de tutumsal yönü bulunmaktadır. Sadakatin davranışsal yönü müşterilerin işletmeden satın alma eylemini tekrarlamasını sağlamaktadır. Tutumsal yönü ise, müşteri satın alma eylemini tekrarlamasa bile işletme hakkında olumlu konuşması, tavsiye etmesi, başkalarını işletmeden alışveriş yapması için ikna etmesidir [21].

İnşaat sektörü kapsamında müşteri yönlülük kavramı incelendiğinde, sektörün gerek ürün gerekse süreç bakımından kendine has doğası gereği müşteri tanımadaki güçlük, müşteri alg1 ve beklentilerindeki değişkenlik, müşteri yönlülüğün önündeki en önemli engeldir [22-28]. İnşaat sektörü, birçok katılımcının (kullanıcı, mal sahibi, mühendis, yüklenici, alt yükleniciler, malzeme sağlayıcılar, vb.) yer aldığı karmaşık bir çalışma ortamıdır. Bu nedenle bu karmaşık çalışma ortamında müşterinin kim olduğunun, beklentilerinin, ürün/hizmet konusunda müşteri algılarının tanımlanması, zaman içinde değişen müşteri ihtiyaç ve beklentilerinin izlenmesi müşteri yönlülüğün önündeki engellerin aşılmasında en önemli belirleyici olarak gösterilmektedir [29]. Yapılan çalışmada [29] inşaat sektöründe müşteri yönlülük kavramı; firma imajı, kalite beklentisi, kalite algısı, değer algısı, müşteri memnuniyeti, müşteri sadakati değişkenlerini içeren Avrupa Müşteri Memnuniyet Endeksi Modeli aracılığı ile incelenmiştir. Önceki çalışmalar incelendiğinde [16-29], kalite beklentisi, kalite algısı, değer algısı müşteri memnuniyeti, müşteri sadakati kavramlarının müşteri yönlülüğün belirlenmesindeki önemi üzerine vurgu yapıldığı görülmektedir. Bu çalışmada kalite beklentisi, kalite algısı, değer algısı müşteri memnuniyeti, müşteri sadakati kavramları ve bu kavramlar arasındaki ilişki mimari tasarım kapsamında incelenmiştir.

İnşaat sektöründe üretimin ilk adımı mimari tasarımdır. Mimari tasarım, restorasyon, restitüsyon, gibi farklı çalışma alanlarında, yapım yönetimi, şantiye organizasyonu, gibi mesleki hizmet alanlarını içerir. Mimari tasarım, müşteri beklentilerinin karşılanmasına yönelik ayrılan kaynakların; teknolojik, çevresel ve hukuksal kısıtlar altında yapı ürününe dönüştürülmesi sürecidir. Mimari tasarımın çıktıları ise, gerekli tasarım dokümanlarını (teknik çizimler, metraj-keşif ve şartnameler) içerir [30]. Bu süreçte yapının hedeflenen fonksiyona uygunluğu, bina içindeki farklı işlevlerin birbirleri ile uyumu ve ilişkisi, teknik mahaller ile kullanım alanlarının birbirleri ile ilişkisi, fiziki uygunluğu, sirkülasyon alanlarının dağılımı, erişim imkanları, fiziki çevresi ile ilişkileri, ergonomi, estetik, kullanım kolaylığı, dayanıklılık tasarım kalitesini belirleyen işlevsel gereksinimlerdendir. Öte yandan mimari tasarımda, yapım sürecine ilişkin şartname, teknik gereklilikler ve standartlara uygunluk önemlidir [30]. Gerek işlevsel gereksinimler gerekse teknik gereksinimler müşteri alg1 ve beklentilerini şekillendirmektedir

Mimari tasarım süreci tasarımcının öznel fikrinin uzantısında bir yapının somutlaştırılması için, müşteri ile yapılan görüşmelerle başlayan, müşteri beklentilerinin tespit edilmesi, beklentilerin nasıl karşılanacağı konusunda çözüm yollarının ortaya konulduğu yapı üretiminin bir aşamasıdır. Tapan [31], bu süreci "problemin tanımlanmasında belirlenen kullanıcı istek ve gereksinmelerine bağlı olarak gelişen değer ölçütlerinin sonuç üründe hangi oranda gerçekleştiğini saptamak" olarak ifade etmektedir. $\mathrm{Bu}$ nedenle müşterinin beklentilerinin doğru ve net belirlenmesi, ortaya 
çıkan tasarım sürecinin ürünü olan proje konusunda müşteri memnuniyetini belirlemektedir.

\section{Araştırma yöntemi}

Çalışmanın bu bölümünde mimari tasarım firmalarının müşteri yönlülüğü incelenmiştir. Bunun için çalışma kapsamında incelenen literatür çalışmaları [2, 26, 27] dikkate alınarak bir kuramsal model geliştirilmiştir. $\mathrm{Bu}$ kuramsal model; 1) müşteri memnuniyetlerinin belirlenmesinde müşteri beklentisi, kalite algısı, değer algısının etkisin olduğunu, 2) müşteri memnuniyetinin müşteri sadakatini etkilediğini önermektedir. Model önerisi Şekil 1' de gösterilmiştir. Araştırmanın hipotezleri ise Tablo 1' de verilmiştir. Araştırmanın belirtilen amaçlarına ulaşabilmesi için önerilen kuramsal model ampirik olarak incelenmiştir.

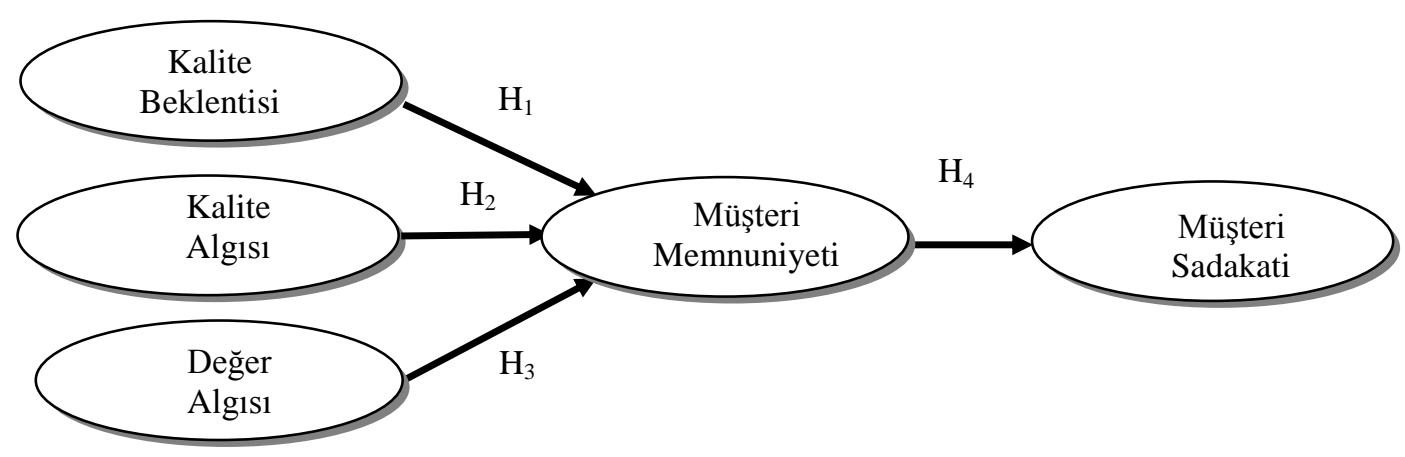

Şekil 1. Kuramsal Araştırma Modeli

Tablo 1. Araştırma Hipotezleri

\begin{tabular}{|l|l|}
\hline Numara & Hipotez \\
\hline $\mathrm{H}_{1}$ & Kalite beklentisi ile müşteri memnuniyeti arasında olumlu bir ilişki vardır. \\
\hline $\mathrm{H}_{2}:$ & Kalite algısı ile müşteri memnuniyeti arasında olumlu bir ilişki vardır. \\
\hline $\mathrm{H}_{3}:$ & Değer algısı ile müsteri memnuniyeti arasında olumlu bir ilişki vardır. \\
\hline $\mathrm{H}_{4}:$ & Müşteri memnuniyeti ile müşteri sadakati arasında olumlu bir ilişki vardır. \\
\hline
\end{tabular}

\subsection{Anket çalışması}

Çalışma kapsamında veriler anket çalışması ile elde edilmiştir. Anket çalışması için bir anket formu geliştirilmiştir. $\mathrm{Bu}$ anket formunda müşteri yönlülüğün belirlenmesine yönelik sorular önceki çalışmalarda güvenilirliği test edilmiş ölçeklerin (sorular ve ifadeler) inşaat sektörüne uyarlanması ile oluşturulmuştur. Ankette yer alan ifadelerin değerlendirilmesinde Likert ölçeğine dayalı olarak verilen yanıtlar 1 (hiç katılmıyorum)'den 7 (tamamen katılıyorum)' ye kadar derecelendirilmiştir. Anket formunda firma yaşı, firmada çalışan sayısı açık uçlu soru şeklinde yöneltilmiştir.

\section{Araştırma bulguları}

Mimari tasarım firmalarının müşteri yönlülügüunün incelemesini amaçlayan bu çalışmanın örneklemi, İnşaat sektöründe faaliyet gösteren yüklenici firmalar dikkate alınarak belirlenmiştir. Araştırmada yer alan müşteri memnuniyetine ilişkin kavramlar 
üst yöneticileri kapsamaktadır. Bu nedenle firma yöneticileri ve teknik ofis müdürleri araştırmanın hedef yanıtlayıcı kitlesi olarak belirlenmiştir. Örneklem ve hedef yanıtlayıcılar belirlendikten sonra, belirtilen kriterlere uyan 156 firma tarafindan anketin yanıtlanması sağlanmıştır. Eksik bilgiler nedeniyle 13 anket formu değerlendirme dışı bırakılmıştır. Anket çalışmasına katılan firmaların genel özellikleri Tablo 2' de verilmiştir. Şekil 2'de anket çalışmasına katılan firmaların \% 32'sinin 1 ile 5 yıl, \% 26' s1 6-10 yıl, \%21'i 11-15 yıl, \% 14'ü 16-20 yıl, \% 7'sinin ise 20 yıl ve daha fazla yıldır bu sektörde faaliyet gösterdiği görülmektedir. Buna göre; \%30'u 1 ile 10 , \%21' i 11 ile $20, \% 17$ 'si 21 ile 30, \%10'u 31 ile 40, \%5'i 41 ile 50 , \% 17'si 50 ve daha fazla sayıda çalışan istihdam etmektedir.

Tablo 2. Ankete katılan firmaların genel özellikleri.

\begin{tabular}{|l|l|l|l|}
\hline \multicolumn{2}{|l|}{ Katılımcıların Profili } & Toplam & Yüzde (\%) \\
\hline \multirow{4}{*}{ Firma Yaşı } & $1-5$ yıl & 46 & $32 \%$ \\
\cline { 2 - 4 } & $6-10$ yıl & 37 & $26 \%$ \\
\cline { 2 - 4 } & $11-15$ yıl & 30 & $21 \%$ \\
\cline { 2 - 4 } & $16-20$ y1l & 20 & $14 \%$ \\
\cline { 2 - 4 } & $21-\ddot{\text { üzeri }}$ & 10 & $7 \%$ \\
\hline \multirow{5}{*}{ Firma Çalışan Sayıs1 } & $1-10$ kişi & 43 & $30 \%$ \\
\cline { 2 - 4 } & $11-20$ & 30 & $21 \%$ \\
\cline { 2 - 4 } & $21-30$ & 24 & $17 \%$ \\
\cline { 2 - 4 } & $31-40$ & 14 & $10 \%$ \\
\cline { 2 - 4 } & $41-50$ & 7 & $5 \%$ \\
\cline { 2 - 4 } & $50-$ üzeri & 24 & $17 \%$ \\
\hline
\end{tabular}

Çalışma kapsamında değerlendirilen kuramsal modelin istatistiksel olarak incelenmesi için anketlerden elde edilen verilerin güvenilirliğinin test edilmesi gerekmektedir. Veriler, istatistiksel analiz programına (SPSS 16) girilmiş, ankette bulunan soruların güvenilirlik analizi yapılmıştır. Değişkenlerin ölçülmesinde sorulan ölçüm sorularının güvenirliliği, Cronbach alfa değerleri ile incelenmiştir (Tablo 3). Güvenilirlik analizi sonucunda 0 ile 1 arasında $(0 \leq \alpha \leq 1)$ değişen değer olan Cronbach Alpha $(\alpha)$ değerinde 1 'e yakın değerler ölçümün güvenilir olduğunu ifade ederken 0.55 'in altında kalan değerler ise ölçümün güvenilir olmadığını ifade etmektedir [32]. Güvenilirlik analizi sonucu elde edilen çalışma kapsamında incelenen standart sapmaları $(\sigma)$ ve Cronbach Alpha $(\alpha)$ değerleri Tablo 3'de verilmiştir. Buna göre güvenilirlik (Cronbach Alpha) katsayısı Müşteri Kalite Beklentisi (KB) için 0.60, Kalite Algısı (KA) için 0.83, Değer Algısı (DA) için 0.70, Müşteri Memnuniyeti(MM) için, 0.73 Müşteri Sadakati (MS) için ise 0.70 bulunmuştur. Değişkenlerin Cronbach Alpha $(\alpha)$ değerini karşıladı̆̆ görülmüştür (Tablo 3). Tablo3 incelendiğinde kategorik olarak ölçülen değişkenler için güvenilirlik analizi kullanılmadığından dolayı çalışma kapsamındaki firma yaşı, firma büyüklügü değişkenleri (firmada çalışan teknik personel ve idari personel sayısı) değeri hesaplanmamıştır.

Değişkenlere ait güvenilirlik analizi yapıldıktan sonra değişkenler arası ilişki düzeyi korelasyon analizi ile belirlenmiştir. Korelasyon analizi iki değişken arasında ilişki olup olmadığını tespit etmek için kullanılmaktadır. Pearson katsayısı (r) ile ifade edilmekte, 1 ile +1 arasında değişmektedir. +1 'e yaklaştıkça pozitif güçlü bir ilişkinin varlığından 1 'e yaklaştıkça negatif yönde güçlü bir ilişkin varlığından söz edilmektedir. Bu çalışma 
kapsamında yapılan anketlerden elde edilen veriler değerlendirilerek kalite beklentisi, kalite algısı, değer algısı, müşteri memnuniyeti, müşteri sadakati faktörleri arasındaki ilişsileri araştırmak için korelasyon analizi yapılmıştır. Korelasyon analizi sonuçları Tablo 4'de verilmiştir. Buna göre; değişkenler arasında pozitif anlamlı bir ilişki vardır. En yüksek değer kalite algısı ile değer algısı ( $r=0.542 ; \mathrm{p} \leq 0.001)$ arasında bulunurken, en düşük değer müşteri memnuniyeti ve kalite beklentisi $(r=0.310 ; p \leq 0.001)$ arasında bulunmuştur.

Tablo 3. Araştırmada kullanılan değişkenlerin standart sapmaları $(\sigma)$ ve Cronbach Alpha $(\alpha)$ değerleri

\begin{tabular}{|l|c|c|}
\hline Değişkenler & Standart Sapma $(\sigma)$ & Cronbach alfa $(\alpha)$ \\
\hline Firma Yaşı & 10.55 & - \\
\hline Firma Büyüklüğ̈ & 29.08 & - \\
\hline Kalite Beklentisi(KB) & 0.76 & 0.60 \\
\hline Kalite Algısı(KA) & 0.75 & 0.83 \\
\hline Değer Algısı(DA) & 0.79 & 0.70 \\
\hline Müşteri Memnuniyeti(MM) & 0.56 & 0.73 \\
\hline Müşteri Sadakati (MS) & 0.61 & 0.70 \\
\hline
\end{tabular}

Çalışma kapsamında geliştirilen kuramsal modelin istatistiksel olarak test etmek için Yapısal denklem modeli (YDM) kullanılmıştır. Yapısal denklem modeli (YDM), diğer istatistiksel yöntemlerden (regreasyon, gibi) ayıran en temel özelliği ise, modelde gösterilen bütün ilişkileri tek defada test edebilme olanağı bulunmasıdır. YDM, değişkenler arasındaki dolaylı ve doğrudan ilişkileri, patika katsayıları $(\beta)$ ile ifade etmektedir. Modelde yer alan $\beta$ ' nın hesaplanması sürecinde en olası tahmin yöntemini kullanmaktadır [33-37].

Tablo 4. Değişkenler arasındaki korelasyon katsayıları.

\begin{tabular}{|l|l|l|l|l|l|}
\hline & \multicolumn{1}{|c|}{ KB } & \multicolumn{1}{|c|}{ KA } & \multicolumn{1}{c|}{ DA } & \multicolumn{1}{c|}{ MM } & MS \\
\hline Kalite Beklentisi(KB) & 1 & & & & \\
\hline Kalite Alg1s1(KA) & $0.357^{* * *}$ & 1 & & & \\
\hline Değer Algıs1(DA) & $0.398^{* * * *}$ & $0.542^{* * *}$ & 1 & & \\
\hline Müşteri Memnuniyeti(MM) & $0.310^{* * *}$ & $0.520^{* * *}$ & $0.542^{* * *}$ & 1 & \\
\hline Müşteri Sadakati (MS) & $0.348^{* * *}$ & $0.528^{* * *}$ & $0.537^{* * *}$ & $0.453^{* * *}$ & 1 \\
\hline
\end{tabular}

$\mathrm{p}^{* * *} \leq 0.001, \mathrm{p}^{* *} \leq 0.01, \mathrm{p}^{*} \leq 0.05$

YDM ile ilişkili çok sayıda uyum ve anlamlılık testi geliştirilmiştir [34]. Bunlara genel olarak uyum indeksi uygunluğu (Goodness of Fit Index; GFI) ismi verilmiştir. GFI değerleri 0 ile 1 arasında değişir ve örneklem genişliğine çok duyarlı olduğu için büyük verilerde daha küçük değerler vermektedir. GFI değeri 1'e ne kadar yakın olursa uyum o kadar iyi demektir. AGFI ise örneklem genişliği dikkate alınarak düzeltilmiş olan bir GFI değeridir. Örneklemin büyük olduğu durumlarda AGFI daha temsili bir uyum indeksidir. GFI ve AGFI dışında, gözlenen değişkenler arasındaki hatanın derecesi temelinde geliştirmiş olan mutlak uyum indeksleri de kullanılmaktadır. Bunların başında yaklaşık hataların ortalama karekökü (Root Mean Square Error of Approximation, RMSEA) indeksi gelmektedir. 0.05 'e eşit ya da daha küçük olan 
değerler mükemmel bir uyumu ifade etmekte, $0.05^{\prime}$ 'den büyük $0.08^{\prime}$ den küçük veya eşit değerler ise kabul edilebilir sınırdadır.

Çalışmanın bu bölümünde geliştirilen kuramsal araştırma modeli istatistiksel olarak test edilmiştir (Şekil 2). Modelde yer alan değişkenler arasındaki ilişki, YDM aracılığı ile belirlenmeye çalışılmıştır. Bunu tespit etmek için Amos 20.0 programından faydalanılmıştır. Modelin geçerliliğini ifade eden uyum kriterleri Tablo 5' de verilmiştir. Modelin uygunluğuna bakıldığında, Araştırma Modeli' ne ait uyum kriter değerleri: $X^{2} /$ serbestlik derecesi=1.735; GFI $=0.947 ; \quad$ AGFI $=0.877 ; \quad$ NFI=0.947; $\mathrm{CFI}=0.976$; ve $\mathrm{RMSEA}=0.046$ elde edilmiştir. Araştırma modeli' nin istatistiksel açıdan değerlendirildiğinde güvenilir bir YDM olduğu sonucu ortaya çıkmaktadır.

Tablo 5. Yapısal Denklem Modeli (YDM) uyum kriterleri [37] .

\begin{tabular}{|l|c|c|}
\hline & Araştırma Modeli & Eşik Değer \\
\hline$X^{2} /$ Serbestlik derecesi & 1.735 & $<3.0$ \\
\hline GFI(Uyum İyiliği İndeksi) & 0.947 & $\geq 0.90$ \\
\hline AGFI(Düzeltilmiş Uyum İyiliği İndeksi) & 0.877 & $\geq 0.80$ \\
\hline NFI(Normlaştırılmış Uyum İndeksi) & 0.947 & $\geq 0.90$ \\
\hline CFI(Karş1laştırmalı Uyum İndeksi) & 0.976 & $\geq 0.90$ \\
\hline $\begin{array}{l}\text { RMSEA(Yaklaşık Hataların Ortalama } \\
\text { Karekökü) }\end{array}$ & 0.046 & $\leq 0.05$ \\
\hline
\end{tabular}

Yapısal denklemin değerlendirilmesinde, bağımlı değişkenlerin determinasyon katsayıları $\left(\mathrm{R}^{2}\right)$, güvenilirlik düzeyi $(\mathrm{p})$ ve değişkenler arasındaki ilişkiler için patika katsayıları $(\beta)$ kullanılmaktadır. Yapısal modelin sonuçları (Tablo 6), müşteri memnuniyeti değer algısı, kalite algısı, müşteri beklentileri ve müşteri sadakatinin ilişkili olduğu görülmektedir. Değer algısı değişkeninin güvenilirlik düzeyi $\mathrm{p} \leq 0.05$ ' den büyük olmasına rağmen, bu eşitliğine yakın bir değer olduğundan değerlendirmeye alınmıştır.

Tablo 6. Değişkenler arasındaki ilişkiler.

\begin{tabular}{|ll|l|l|l|}
\hline Değiş̧kenler & $\beta$ & $\mathrm{P}$ & $\left(\mathrm{R}^{2}\right)$ \\
\hline $\mathrm{MM}$ & $\leftarrow \mathrm{DA}$ & 0.373 & .007 & \\
$\mathrm{MM}$ & $\leftarrow \mathrm{KA}$ & 0.576 & $* * *$ & \\
$\mathrm{MM}$ & $\leftarrow \mathrm{KB}$ & -0.220 & .051 & $0.61^{*}$ \\
$\mathrm{MS}$ & $\leftarrow \mathrm{MM}$ & 0.821 & $* * *$ & $0.67 * * *$ \\
\hline
\end{tabular}

Değer algıs1, kalite algıs1 ve müşteri beklentileri müşteri memnuniyetini $\% 61\left(\mathrm{R}^{2}=0.61\right.$, $\mathrm{p} \leq 0.05)$ oranında açıklarken, müşteri memnuniyeti, müşteri sadakatini $\% 67\left(\mathrm{R}^{2}=0.67 \mathrm{p}\right.$ $\leq 0.001)$ oranında açıklama gücüne sahiptir. Bulgular; değer algısı $(\beta=0.373 \mathrm{p}=0.07)$ ve kalite algısının ( $\beta=0.576 \mathrm{p} \leq 0.001)$ müşteri memnuniyetini pozitif yönde etkilediğini, müşteri beklentilerinin $(\beta=-0,220 \mathrm{p} \leq 0.05)$ ise müşteri memnuniyetini negatif yönde etkilediğini göstermektedir. Ayrıca sonuçlar müşteri memnuniyetinin müşteri sadakatini $(\beta=0,821 \mathrm{p} \leq 0.001)$ pozitif yönde etkilediğini göstermektedir. Elde edilen değerlerin istatistiksel açıdan anlamlı olduğu görülmektedir. Bu sonuçlara göre, önerilen $\mathrm{H}_{1}, \mathrm{H}_{2}$, $\mathrm{H}_{3}, \mathrm{H}_{4}$ hipotezleri kabul edilmiştir. 


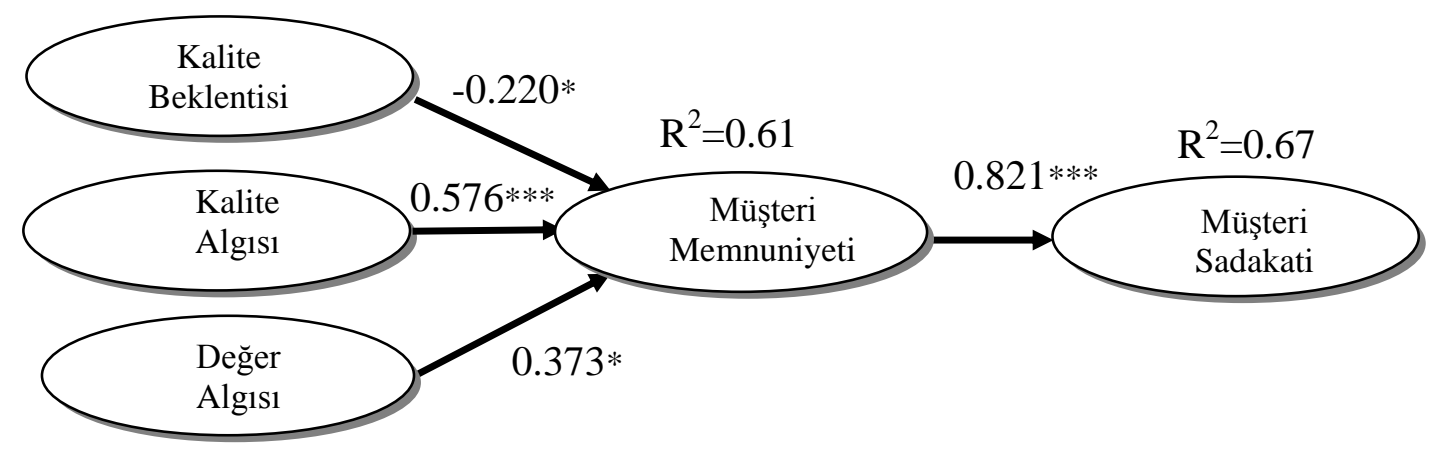

Şekil 2. Kuramsal Araştırma Modeli

\section{Sonuçlar}

Bu çalışmada inşaat sektöründe müşteri yönlülük mimari tasarımın müşterilerinden olan yüklenici firmalar örneklemi özelinde araştırılmıştır. Bunun için bir kuramsal model geliştirilmiştir. Kuramsal model; kalite beklentisi, kalite algısı, değer algısının müşteri memnuniyetini etkilediğini müşteri memnuniyetinin ise müşteri sadakatini etkilediğini önermektedir. Kuramsal modelin analizinde yapısal denklem modeli (YDM) kullanılmıştır. Analiz sonuçları müşteri memnuniyeti ile değer algısı, kalite algısı, müşteri sadakati arasında pozitif anlaml, müşteri beklentileri ile müşteri memnuniyeti arasında ise negatif anlamlı bir ilişkinin olduğunu ortaya koymuştur. Bunun nedeni müşterinin beklentilerinin atması memnuniyetini olumsuz etkilemesi olabilir. Ayrıca korelasyon analizi sonuçları değişkenler arasında ilişkinin olduğunu göstermektedir.

$\mathrm{Bu}$ sonuçlar doğrultusunda, kalitenin istenen düzeyde olması ve müşteri tarafından bu kalitenin algılanması, müşterinin firmaya bakış açısını olumlu yönde etkilemekte müşteri memnuniyetinin sağlanmasında önemli faktörler olmaktadır. Müşteri memnuniyetinin sağlanması müşterinin tekrar hizmet alma davranışını tekrarlayacağı gibi olumlu düşüncelerini başkaları ile paylaşarak müşteri potansiyelini artıracaktır.

Yapının hedeflenen fonksiyona uygunluğu, bina içindeki işlevlerin birbiriyle ilişkisi, sirkülasyon alanlarının dağılımı, erişim imkanları, fiziki çevresi ile ilişkileri, ergonomi, estetik, kullanım kolaylığı, dayanıklılık tasarım kalitesini belirleyen işlevsel gereksinimlerdendir. Aynı zamanda yapım sürecinde şartname, teknik gereklilikler ve standartlara uygunluğu tasarımın kalitesini belirleyen teknik unsurlardır. Tasarım aşamasında bu gereksinimlerin karşılanmasına yönelik beklentilerinin ortaya konulması, problem çözümlerinde müşterinin bu unsurları nasıl algıladığının değerlendirilmesi, yüklenici firmalar ve onların müşterisi yapı ürününü kullanan son kullanıcıların memnuniyetini arttıracaktır.

İnşaat sektöründe çoğu kez firmalar üretime başlama noktasında gerekli sermayeyi bulabilmek için proje üzerinden satış yapmaktadır. Yapıyı kullanacak son kullanıcı ve yüklenici arasındaki anlaşma tasarım dokümanları (teknik çizimler, metraj-keşif ve şartnameler) üzerinden yapılmaktadır. Tasarım aşamasında teknik çizimlerin kalitesi yüklenici firma ve son kullanıcı arasındaki iletişimi güçlendirecektir. Teknik gereklilikler ve standartlara uygun tasarımlar ise yapı üretim aşamasında ortaya çıkacak anlaşmazlıkları önlemeye yardımcı olacaktır. 
İnşaat sektöründe müşteri yönlülük kavramını inceleyen bu çalışmanın sonuçları 1şığında; bu sektörde faaliyet gösteren firmaların, müşteri memnuniyeti düzeyini artırmak için, müşterinin istek, beklenti ve gereksinimlerinin sistematik biçimde değerlendirmesi gerekmektedir. Firmaların rakip firmaların stratejilerini yakından izlemeleri çalışanlara müşteri yönlü bir bakış açısı kazandırılmaları önemlidir.

Yapılan bu çalışma bulguları örneklem ile sınırlıdır. $\mathrm{Bu}$ çalışmanın örneklemi genişletilerek inşaat sektöründe faaliyet gösteren diğer meslek profesyonellerini de kapsaması sektör düzeyinde sonuçlara ulaşmayı sağlayacaktır.

\section{Kaynaklar}

[1] Özçakar, N., Bir kamu kuruluşundaki toplam kalite yönetimi uygulamalarının değerlendirilmesi, İstanbul Üniversitesi İşletme Fakültesi Dergisi, 39, 1, 106124, (2010).

[2] Türkyılmaz, A. ve Özkan, C., Development of a customer satisfaction index model: An application to the Turkish mobile phone sector, Industrial Management and Data Systems, 107, 5, 672-687, (2007).

[3] Küçükergin, K.G., Müş̧teri sadakatinin oluşum sürecine müşteri tatmini ve ataletin etkisi: yiyecek-içecek işletmelerine yönelik bir uygulama, Yüksek Lisans Tezi, Gazi Üniversitesi, Eğitim Bilimleri Enstitüsü, Turizm İşletmeciliği Eğitimi Ana Bilim Dalı, (2012)

[4] Strong, C.A. ve Haris, L.C., The drivers of customer orientation: An exploration of relational, human resource and procedural tactics, Journal of Strategic Marketing, 12, 183- 204, (2004).

[5] Kohli, A. ve Jaworsky, B.J., Market orientation: The construct, research propositions, and managerial implications, Journal of Marketing, 54, 1-8, (1990)

[6] Kohli, A.K., Jaworsky, B.J. ve Kumar, A., Markor, A measure of market orientation, Journal of Marketing Research, 30, 4, 467-477, (1993).

[7] Türkkan, C., Örgütsel hizmet pazarlarında müşteri odaklı pazarlama yaklaşımı, Yüksek Lisans Tezi, İstanbul Teknik Üniversitesi, Fen Bilimleri Enstitüsü, İşletme Mühendisliği Anabilim Dalı, (2006).

[8] Öngenel, N., İşletmelerde girişim odaklılık, müşteri odaklılık ve firma performansına etkisi, Yüksek Lisans Tezi, Beykent Üniversitesi Sosyal Bilimler Enstitüsü İşletme Yönetimi Anabilimdalı, İşletme Yönetimi Bilim Dalı, İstanbul, (2009).

[9] Günaydın, $\quad$ M., Toplam $\quad$ Kalite www.iyte.edu.tr/ muratgunaydin/TKY3.doc, (10.05.2017)

[10] Slater, S.F. ve Narver, J.C., Does the competitive environment moderate the market orientation-business performance relationship, Journal of Marketing, 58, 46-56, (1994).

[11] Naktiyok, A. ve Timuroğlu M.K., Öğrenme yönlülügüün müşteri yönlülük üzerine etkisi, Erciyes Üniversitesi İktisadi ve İdari Bilimler Fakültesi Dergisi, 30, 169-192, (2008).

[12] Webster, Jr. F.E., Market-driven management using the new marketing concept to create a customer-oriented company. John Wiley and Sons, New York (1996). 
[13] Yıldırım, M., Kamu yönetiminde yeni bir ikilem: yurttaş odaklılık yada müşteri odaklılık, Celal Bayar Üniversitesi iktisadi ve İdari Bilimler Dergisi, 10, 1, 99-115, (2009).

[14] Deshpande, R., Farley J.U. ve Webster, Jr. F.E., Corporate culture, customer orientation, and innovativeness in Japanese firms: A quadrad analysis, Journal of Marketing, 57, 1, 23-37, (1993).

[15] Appiah-Adu, K. ve Singh, S., Customer orientation and performance: A study of SMEs, Management Decision, 36, 6, 385-394, (1998).

[16] Gedik, S., Son kullanıcıya erişen otomotiv firmalarında müşteri odaklılık değerlendirmesi, Yüksek Lisans Tezi Marmara Üniversitesi, Fen Bilimleri Enstitüsü, Endüstri Mühendisliği Anabilimdalı, (2007).

[17] Schiffman, L.G. ve Kanuk, L.L. Consumer behavior. New Jersay: Prentice Hall, (2000).

[18] Zaim, S., Türkyılmaz, A. Tarım, M. ve Ucar, B., Akkas, O., Measuring customer satisfaction in Turk Telekom Company using structural equation modeling technique, Journal of Global Strategic Management, 10, 1, 89-99, (2010).

[19] Fornell, C, Johnson, M.D., Anderson, E.W., Cha, J., ve Bryant, B.E., The American customer satisfaction index: Nature, purpose and findings, Journal of Marketing, 60, 7-18, (1996).

[20] Demir, Ş.Ş., Avrupa müşteri memnuniyet endeksi modeli: Uluslararası otel işletmelerine yönelik bir uygulama, Uluslararası İnsan Bilimleri Dergisi, 9, 672-695, (2012).

[21] Demir, O. ve Kırdar, Y., Müşteri ilişkileri yönetimi: CRM, Review of Social, Economic and Business Studies, 7, 293-308, (2006).

[22] Karvien, K. ve Benbett, D., Enhancing performance though the introduction of customer orientation in the building components industry, International Journal of Productivity and Performance Management, 55, 5, 400-422, (2006).

[23] Karna, S., Jinnonen, J.M., ve Sorvala V.M., Modeling structure of customer satisfaction with construction, Journal of Facilities Management, 7, 2, 111127, (2009).

[24] Edum-Fotwe, F.T., Price, A. ve Thorpe, A., Analysing construction contractors' strategic intent from mission statements, CIB W65 Proceedings, The Organization and Management of Construction: Shaping Theory and Practice, Glasgow, UK, (1996)

[25] Wilson, D.T. ve Pelham, A.M., A longitudinal study of the impact of market structure, firm structure, strategy and market orientation on dimensions of performance, Journal of the Academy of Marketing Science, 24, 27-43, (1996).

[26] Dulaimi, M.F., Baxendale, A.T. ve Jewell, M.R., Refocusing construction to meet customer requirements, CIB W65 Proceedings, The Organization and Management of Construction: Shaping Theory and Practice, 187-96, Glasgow, UK, (1996).

[27] Dulami M.F., The challenge of customer orientation in the construction industry, Construction Innovation, 5, 3-12, (2005).

[28] Preece, C. ve Tarawneh, S., Service quality for client catisfaction on design and build, Association of Researchers in Construction Management Conference Proceedings, Cambridge, UK., (1997). 
[29] Çivici, T., Yapım sektöründe müşteri yönlülük, 2. Proje ve Yapım Yönetimi Kongresi, 13 - 16 Eylül 2012 İzmir Yüksek Teknoloji Enstitüsü, Urla-İzmir, (2012),

[30] Alptekin, G.Ö. ve Kanoğlu A., Yapı üretiminde tasarım kalitesini yükseltmeye yönelik bir modelin kavramsal yapısı ve bileşenleri, ITÜ Dergisi/a Mimarlık, Planlama, Tasarım, 6, 2, 3-12, (2007).

[31] Tapan, M., Mimarlıkta değerlendirme, İTÜ Yayınevi, Maçka, İstanbul, (2004).

[32] Van de Ven, A., Ferry, D., Measuring and assessing organizations, Wiley, NewYork. (1979).

[33] Byrne, B.M, Structural equation modeling with AMOS, Routledge, NewYork. (2010).

[34] Arbuckle, J.L., , Amos 4.0 Users Guide2, SPSS Inc. (1999).

[35] Dong, L., Neufeld, D. ve Higgins, C., Testing Klein and Sorra's innovation implementation model, Presented at Academy of Management Conference, Hawaii, (2005).

[36] Bentler, P.M. ve Chou C.P., Practical issues in structural modeling, Sociological Methods and Research, 16, 1, 78-117, (1987).

[37] Hoyle, R.H. ve Panter, A.T., In structural equation modeling: Concepts, issues and applications, Sage Publications, London, (1995). 